УДК 162-2: 1

Гурбанська А.І.

доктор філологічних наук, професор Київський національний університет культури і мистецттв.

\title{
ПОЕЗІЯ ОЛЕГА ОЛЬЖИЧА: ОНТОЛОГІЧНА ТРІАДА «ДУХ-ВОЛЯ-ВІРА»
}

Поезію О. Ольжича розглянуто у зв'язку з витоками ци особливостями художнього втілення онтологічної тріади «дух-воля-віра», його історіософською кониепцією. 
Ключові слова: онтологічна тріада «дух-воля-віра», історіософія, національне, героїчне минуле, система образів, художній світ.

Поэзия О. Ольжича рассмотрена в связи с истоками и особенностями художественного воплощения онтологической триады «дух-воля-вера», его историософской конияепцฺией.

Ключевые слова: онтологическая триада «дух-воля-вера», историософия, национальное, героическое прочлое, система образов, художественный мир.

The article considered $O$. Olzhych's poetry in connection with the origins and characteristics of artistic embodiment ontological triad «spirit-will-faith», his historiosophical concept.

Key words: ontological triad «spirit-will-faith», historiosophy, national, heroic past, imagery, artistic world.

В історію вітчизняної культури, науки і політичної думки Олег Кандиба (Ольжич) увійшов як особистість героїчного складу, незламний борець за державність України. Світ його творчих зацікавлень, наукових і політичних проектів, охоплюючи Україну в широкому діапазоні історичних подій від Х до 40-х pp. ХХ ст., 3 відстані часу все більше вияскравлюється вольовими імперативами, закликами до пориву, діяння, оптимістичною спрямованістю в майбутнє, високою культурою й досконалістю поетичного виразу, на що слушно звертають увагу Ю. Ковалів, Г. Клочек, М. Ільницький та інші літературознавці. Проте й досі не висвітленою залишається проблема зв’язку онтологічної сутності лірики О. Ольжича 3 художністю, поетологічними технологіями, «різьбленістю» його слова, на дослідження чого і спрямована мета цієї студії.

Генеза художньої візії онтологічної тріади «дух-воля-віра»в поезії О. Ольжича пов'язана 3 реальними обставинами особистого характеру та 3 інтенсивним розвитком у мистецтві онтологічної тенденції зосередженою увагою до індивідуального буття особистості, національного героїчного минулого, трагічної історії нації та іiї духовного

Літератури світу: поетика, ментальність і духовність. - 2014. - Вип. 4. 
єднання. 3 дитинства Олег Кандиба (псевдонім Ольжич походить від давньоруського князя Олега) викликав у своєї матері тривожні передчуття трагічної долі. В одному з листів до його батька О. Олеся (від 16.09.1921) Віра Антонівна з відчаєм написала: «Аx, породивии дитину, роби з неї кого хочеш: англійця, поляка, зулуса, орангутанга, накінещьь - тільки не україния, бо, поступаючи інакще, приносиш велику жертву на вівтар патріотизму, на жертвеник вітчизни» [Ольжич 1994 : 314].

У цьому зв'язку варто наголосити, що Олегові Кандибі судилася незвичайна доля. Він із 16 років жив у Берліні, навчався в Карловому університеті (Прага), подорожував і здійснював археологічні розкопки по всій Європі, досліджував археологічні колекції в музеях Львова, Кракова, Праги. Згодом блискуче захистив 3 археології докторат на тему «Неолітична мальована кераміка Галичини» i став перспективним спеціалістом із слов’янської археології. Він займав посаду асистента на кафедрі археології Українського Вільного Університету (Німеччина), читав лекції в Гарвардському університеті (США), куди був запрошений на посаду доцента, брав участь у міжнародних археологічних симпозіумах і конференціях. Напередодні Другої світової війни заснував Український Науковий Інститут в Америці, підготував до друку перший «Збірник» наукових праць цього Інституту. Проте найбільше «божественне задоволення» О. Ольжичу приносила інша муза - література, яка, пануючи над серцем, викристалізувала його історіософські погляди й націоналістичний світогляд. Під впливом професії археолога, у процесі професійних занять, сформувалася одна 3 визначальних рис художнього мислення митця - здатність до інтенсивного образного відтворення прадавніх часів.

Здобувши грунтовну класичну освіту 3 культом Еллади та Давнього Риму, О. Ольжич був ученим-археологом високого професійного рівня, інтелектуалом високої проби, зорієнтованим на неокласичну систему літературно-художнього мислення. Щедро обдарований природою мистецьким даром та інтелектуальною потужністю, О. Ольжич, як слушно 
підмітив Г. Клочек, «був здатний акумулювати найбільш перспективні художні тенденції своєї доби, його художнє мислення $\epsilon$ ідеально згармонізованим у всіх визначальних моментах»; авангардизм О. Ольжича в тому, що «він йшов на крок попереду інших у мистещ̧ькій обробці слова, користуючись при цььму найбільи ефективними поетикальними технологіями», що «було одухотворене иляхетною $i$ глибоко гуманістичною національною ідеєю» [Клочек 2007 : 295]. Зорієнтований на неокласичну систему літературно-художнього мислення, О. Ольжич сповідував високу культуру слова, класичну ясність і точність, прозорість думки, культурологічну наснаженість образів.

На світогляд О. Ольжича, його історіософський доробок і художнє втілення в поетичній творчості онтологічної тріади «дух-воля-віра» великий вплив мав ідеолог українського націоналізму Д. Донцов: ідеологія Д. Донцова відкривала перед О. Ольжичем, як і перед поетами «Празької школи», перспективу самоствердження завдяки формуванню твердої вдачі, сильного діяльного характеру і високої моральної дисципліни. Поет творив у переконанні: «Тільки національна культура, оперта на духовній природі та історичній традиції, забезпечує органічний вияв творчих сил одиниці й нащ̧ї̈» [Ольжич 1994: 205]. Ставлячи акценти на «імперативі волі» сильної особистості 3 індивідуально й національно виразним характером, 3 цільною й цілеспрямованою вдачею, О. Ольжич реалізував свою авторську позицію з прицілом на ідеал «волюнтаристської людини» Д. Донцова, що перегукується $з$ естетичним мисленням Дж. Лондона, А. де Сент-Екзюпері, I. Багряного, У. Самчука. При цьому творчий підхід митця збігається із твердженням філософів-екзистенціалістів: «для повного осягнення справжнього сенсу свого існування людина повинна пройти такі етапи: етап відчуття своєї вкинутості у цей світ $і$ своєї покинутості в ньому, етап «межової ситуації» - усвідомлення конфлікту зі світом та свого невдоволення, щзо й приводить до самоаналізу, пізнання та вибору власних життєвих вартостей, $i$ етап вільного та свідомого вибору дотримуватися цүих вартостей у своєму житті» [Онишкевич 1996 : 243]. 
Екзистенційний дискурс творчості О. Ольжича, як і митців «Празької школи», пояснюється переживаннями 3 приводу втрати Україною можливості бути незалежною, європейським народом 3 ознаками повноцінної особистісної характеристики ії громадян та душевним болем 3 приводу розлуки з батьківщиною.

Онтологічна тріада «дух-воля-віра», домінуючи в художньому світі поетичної творчості О. Ольжича, тісно пов'язана 3 темою України (національною ідеєю), яка, на відміну від його літературознавчих та культурологічних праць («Сучасна українська поезія», «Голод і сучасна українська література», «Українська культура» та ін.), виражена менш прямолінійно, переважно простежуючись у підтекстовій площині віршів.

Збірки поезій О. Ольжича «Рінь» (1935), «Вежі» (1940), «Підзамчя» (1946), а також вірші, що «поза збірками», презентують свого автора як літератора, науковця, філософа, політика, схильного до власного трактування історичних подій і постатей, що відбувалось у світлі категорій «героїчний світогляд» i «героїчна духовність»; вони засвідчують, що, тяжіючи до органічного синтезу традиції та модернізму, О. Ольжич чільне місце відводив сильній, незалежній, творчій особистості, здатній самотужки торувати свій життєвий шлях. Його твори, 3 одного боку, публіцистичні, наснажені пафосом боротьби, а 3 іншого - віддзеркалюють фахові знання археолога, історика, філософа, виражають концепцію єдності минулого, сучасного й майбутнього. Художній світ, система образів, поетичних форм і принципів лірики О. Ольжича пов'язані з його світоглядом, історіософською концепцією світу, з метафізикою героїчного як життєвої настанови й естетичної категорії. Образи-символи національного, інтелектуального, психологічного характеру виражають ключові лексеми: воля, меч, лезо, кремінь, камінь, бронза, залізо, сталь та ін. Намагаючись оживити історію і звертаючись до окремих матеріальних предметів (камінь, уламки кераміки, рінь - галька, дрібне каміння та ін.), митець поєднує «камінність» людського характеру 3 енергією дію, що визначає його поетичну модель. 
У поезії О. Ольжича завдяки можливостям історіософії та художньому аналізу вчинків вольових i войовничих предків на основі онтологічної тріади «дух-воля-віра» сконструювано нову модель життя та образ героя-пасіонарія. За сприяння формуванню абсолютно нової особистості лірику О. Ольжича особливо цінував Є. Маланюк, вважаючи їі надбанням «иілком нової доби в історї нашої Батьківщчини (а може, $і$ в icmopiï свіmy)» [Ольжич 1994 : I, 337]. Художній світ О. Ольжича, як відображення його історіософської концепції, вражав Є. Маланюка своєю артистичною логікою i переконливістю, що дало підстави для такої характеристики: «Від першого до останнього вірша свого Ольжич-поет $є$ передовсім творча Воля (характер), є Муж, що з'явився на світ не «спостерігати» й «оспівувати», не «переживати» й «відтворювати» його, але свідомо його творити, співтворити той світ» [Маланюк 1962 : I, 337].

Під впливом «героїчного світогляду» О. Ольжич культивував «героїчну духовність», що в його трактуванні «значить натугу змагання одиниці й цілого народу до суспільно-морального ідеалу. Це духовність героя, в якій почуття й змагання одиниці й загалу лучаться у вищу єдність, відмінну від свідомости індивідуалізму й колективізму». Саме така «філософрія не протиставлення ц̆ не підпорядкування одиниці масі, а філософія нестримного росту особистости в ім'я спільноти» [Ольжич 1994 : 231] і визначає ідейно-художню сутність лірики О. Ольжича та інших «пражан» (Є. Маланюк, Ю. Дараган, Л. Мосендз, Ю. Липа, О. Теліга). Як археолог та історик Ольжич-поет «прагне просвітити товщу століть і тисячостоліть, шукаючи духовних витоків усього людства i власного роду-племені» [Ольжич 1994 : 127]. Його багатогранна діяльність відбувалася в переконанні: «Тільки національна культура, оперта на духовній природі та історичній традицій, забезпечує органічний вияв творчих сил одиниці й нації» [Ольжич 1994 : 205].

На думку О. Ольжича, «провідна ідея української духовности - це «слава» впродовж изілої історичної перспективи» [Ольжич 1994 : 205]. Ця ідея найбільш виразно втілена в образі Данила Галицького («Данило»): 
«Князь наказав збирати рать» - і як наслідок: «Не чеське срібло - сяйвом попереду / Огненна слава йде Войовнику» [Ольжич 1994 : 105]. За Ю. Ковалівом, «переведення традииійної «філософії серия» у нову якість філософію чину» - відповідало характерові пасіонарія, здатного, не чекаючи ні на сприятливий час, ні на сумнівну сторонню допомогу, відповісти, глибоко засвоївши гіркотні уроки національної минувшини, на суворий виклик дійсності» [Ковалів 2004 : 12].

Саме тому поезію О. Ольжича Ю. Бойко назвав «бойовою», що «оперує рвучкими гаслами. Але вона ц̆ інтелектуалістична, насичена символами й натяками, багата на історичні ремінісценщії, іноді вона сплітає в одно звучання ци колір; вона вимагає від читача деякого рівня естетичної культури і вдумливости» [Бойко 1992 : 288].

У вірші «Галли» крізь призму історіософічності автор проглядає в минуле, сучасне i майбутнє. Орієнтиром для О. Ольжича $є$ галли войовничий давній народ, який жив переважно на території сучасної Франції, його кипуча енергія, відвага, потяг до незвіданих просторів і їхня доба - доба формування молодих народів:

О, невмолимі скам'янілі дні!

Міџуна рука над людьми і богами!

... Ще не одні

Нам скоряться. Над все є вірна криця.

Та нам також судилося розбиться

Колись і десь об гори кам'яні [Ольжич 1994 : 66].

Розкриваючи за допомогою метафоричних епітетів («невмолимі скам'янілі дні») складність епохи галлів, автор уславлює їхнє прагнення самоствердитися міццю «вірної криці».

«Вік героїв величний надходить» [Ольжич $1994: 114$ ], - стверджує О. Ольжич у вірші «Все бурхливіші крила негоди» (1930), звертаючись до образів меча, заліза й міді як утілення рішучості й непохитності героївпасіонаріїв у боротьбі за омріяні ідеали.

Створюючи образ нового покоління українських патріотів, до поезії «Воно зросло з шукання і розпуки» О. Ольжич узяв епіграф із твору 
П. Филиповича («А гострозоре, мужнє покоління / Уже росте на молодій землі»). Митець інтерпретує його як фізично й морально досконале, «безжурно-мужнє, повне буйних сил, / Закохане в свої тугї̈ луки / I в бронзу власних мускулястих тіл» [Ольжич $1994:$ 73] й у такий спосіб орієнтує читачів на «оптимізм, бадьорість, впевненість» (Л. Череватенко). Це вірш-маніфест, у якому лаконічними й чіткими висловами О. Ольжич декларує утвердження нової людини й нової психології української молоді - енергійних, упевнених у собі борців.

Поема О. Ольжича «Грудень 1932» (1933) із збірки «Вежі» (1940), що має жанрові ознаки реквієма, присвячена жертвам антиукраїнської політики польської влади та радянського режиму. Зміст твору - «слова, що прості і суворі» - це переважно декларативні вислови і гасла, звернені до патріотів (товаришів-братів): «Товарищу любий мій, брате, / Опоро моя одна!»; «ваш шлях, як струна, прямий»; «кремінно-тверда воля / Того, щьо $\epsilon$ зв'язковий» та ін.

Товаришу любий мій, брате,

Дивися у вічі рабам,-

Як будете так воювати,

Вкраїни не бачити вам! [Ольжич 1994 : 84], - наказує й застерігає митець.

Через контраст - до суті предмета і явища - це улюблений творчий принцип О. Ольжича. Слабкості духу поет протиставляе «неугнутість» волі і віру, яку уособлює граніт:

Для тих, що, нікчемні і кволі,

Заквилять про зламаний цъвіт, -

Неугнутість нашої волі

I нашої віри граніт! [Ольжич 1994 : 84].

О. Ольжич, як і інші колеги-«пражани» (Є. Маланюк, Ю. Липа, О. Теліга та ін.), пропонував принципово новий «національний міф», у якому «колишньому уявленню про ідилічний світ краӥни протиставляли своє бажання зробити з украӥнців войовничу націю» [Кривчикова 2002 : 5]. 
Художньою ілюстрацією цих ідей є і вірш О. Ольжича «Нащо слова? Ми діло несемо», у якому виражається впевненість:

Бо ж нам дано знайти життя само

В красі неповторимій і суворій [Ольжич 1994 : 74].

На запитання: «Що вибереш: чи образ бездоганний, / А чи праобраз для усіх один?» звучить переконлива відповідь:

Міиніша - віра і дзвінкіший - чин

За словоблудіє і за тимпани! [Ольжич 1994 : 75].

О. Ольжич пропагує поняття: «Одвага. Непохитність. Чистота» i поєднує їх з вольовими імперативами: «Милуйтеся! Беріть! I будьте, будьте!..» [Ольжич $1994: 75]$.

Висвітлюючи реальну дійсність українського підпілля, твір «Незнаному Воякові» (1935) найповніше виражає культ «неугнутої» героїчної особистості, принципи національного аристократа духу, сильний тип людини - українця. У центрі уваги автора й неоромантичного образа ліричного героя екзистенційний вибір безстрашного юнака - боротьба за щастя народу без будь-якого розрахунку, його самовідданість у боротьбі, здатність до межового напруження у змаганні за свободу народу і нації. Тогочасна політична ситуація була такою, що українська державність могла бути виборонена тільки шляхом збройної боротьби: завдяки самоаналізу стало зрозумілим, що державність можна відвоювати тільки за умови зміцнення національного духу. О. Ольжичу імпонувала думка Д. Донцова про необхідність зміцнення національної волі (національного характеру) і віри в позитивний результат майбутньої визвольної боротьби - побудову незалежної української держави. Поет абсолютизує волю людини і міць ï духу, наголошує на їхньому значенні як рушійної сили людських діянь:

Захочеш - $і$ будеш. В людині, затям,

Лежить невідгадана сила [Ольжич 1994 : 88].

Водночас О. Ольжич наголошував i на небезпечності обраного шляху, у тривожному передчутті він прорікав і долю борців, і свою власну: Зрослась небезпека з відважним життям, 
Як з тілом смертельника крила [Ольжич 1994 : 89].

I все ж, гартуючи ідеями націоналізму духовну силу i моральну волю, О. Ольжич прагнув до найвищої самореалізації в духовному вимірі, закликав до цього інших, «заряджав» духовною енергією й орієнтував на «присутність великої і чинної віри»:

O, вірте, всі мури земного впадуть,

Як серие обернеш у сурму!

Найвищі-бо вежі духовности ждуть

Твойого шаленого штурму [Ольжич 1994 : 94].

Чіткість i карбованість віршових рядків, їх наближення до афористичності, для якої прикметна максимальна сконденсованість думки й почуття, репрезентує «монументальний класицизм» (В. Державин) лірики О. Ольжича. Як слушно наголосив Ю. Ковалів, О. Ольжич «тяжів до органічного синтезу традиції та модернізму (хоч i не визнавав авангардизму), прагнув поєднати інтелектуалізоване діонісійство представників «Празької школи» [..] 3 вітаїстичним аполлонійством «неокласиків», до яких себе не зараховував. А втім, чільне місце в мистецтві (та й у житті) відводив сильній, незалежній, творчій особистості, здатній самотужки торувати свій шлях, котрий би не нагадував будь-чий» $[3,8]$. Таким він був сам у реальному житті і в творчості. О. Ольжича вірив, що в недалекому майбутньому на Україну «зіпреться історія нового європейського духа». У вірші «Присвята» (1931) в ім’я України він просив у долі:

Пошли мені, молюся, дар один:

В ім'я ї̈ прийняти мужньо муки

I в грізні дні залізної розплати

В шинелі сірій вмерти від гранати [Ольжич 1994 : 118].

Після арешту у Львові (25 травня 1944 р.), перевезення до Берліна, багатоденних допитів і катувань у концентраційному таборі Заксенгаузен 10 червня 1944 р. О. Ольжич помер. Феномен його як людини, поета i вченого - у нерозривному зв’язку життя і діяльності із трагічною смертю, 
як і феномен усієї «Празької школи». Має рацію І. Руснак: «доля О. Ольжича, О. Теліги, Ю. Липи - цих «лицуарів абсурду» (О. Теліга) засвідчила, щзо сповідувані ними ідеали не розходилися з конкретними справами. Своєю творчістю «трагічні оптимісти» притлумлювали загрозливих розмірів процеси явного $і$ прихованого духовного руїнництвва, викорінювали $з$ характерів співвітчизників рабськість, покірність, м'якотілість - все, щзо нівелювало такі моральні цінності, як иляхетність, мужність, індивідуалізм» [Руснак 2009 : 30]. Художньо конструюючи нову модель життя на основі онтологічної тріади «дух-волявіра» й використовуючи систему поетичних форм та принципів, що виражали його світогляд, О. Ольжич зробив свій вибір: він боровся за українську душу, за посилення енергії народу в його пориванні до свободи й незалежності, прагнув поєднати своїх співвітчизників консолідуючою ідеєю державності України.

\section{БІБЛІОГРАФІЯ}

Бойко 1992 - Бойко Ю. Вибрані праці / Юрій Бойко. - К. : Медекол, 1992. - 380 c.

Клочек 2007 - Клочек Г. Д. Про деякі особливості художнього мислення Олега Ольжича // Енергія художнього слова: зб. статей. - Кіровоград: РВЦ КДПУ ім. В. Винниченка, 2007. - С. 285-295.

Ковалів 2004 - Ковалів Ю. «Празька школа»: від «філософії серця» до «філософії чину» / Юрій Ковалів. - К. : В-во «Бібліотека українця», 2004. -120 с.

Кривчикова 2002 - Кривчикова О. В. «Національний міф» та його трансформація в українській еміграційній поезї (на прикладі «Празької школи»): автореф. дис. на здобуття наук. ступеня канд. філол. наук / О. В. Кривчикова . - К., 2002. - 19 с.

Маланюк 1962 - Маланюк Є. Книга спостережень: Проза / Євген Маланюк. - Торонто : Гомін України, 1962. Т. I -528 с.; Т. II. - 480 с.

Ольжич 1994 - Ольжич О. Незнаному Воякові: Заповідане живим / О. Ольжич. - К. : Фундація імені О. Ольжича, 1994, - 432 с.

Онишкевич 1996 - Онишкевич Л. Екзистенціалістська модель у теорії літератури / Лариса Онишкевич // Слово. Знак. Дискурс. Антологія світової літературно-критичної думки ХХ ст. - Львів : Літопис, 1996. - С. 243-244. 
Руснак 2009 - Руснак I. Є. Художня історіософія Уласа Самчука: монографія / I. Є. Руснак. - Вінниця : ДП «Державна картографічна фабрика», 2009. - 368 c. 